Open Access

\title{
A study on policy literacy and public attitudes toward government innovation- focusing on Government 3.0 in South Korea
}

\author{
EunHyung Park ${ }^{1}$ and Jea-Wan Lee 2* $^{*}$
}

\author{
* Correspondence: \\ noso791@gmail.com \\ ${ }^{2}$ College of Liberal Arts, Wonkwang \\ University, 460 lksan-daero, Iksan, \\ Jeollabuk-do, Korea, Republic of \\ Full list of author information is \\ available at the end of the article
}

\begin{abstract}
This study aims to verify the relationship between policy literacy and attitudes toward the government innovation initiative known as Government 3.0. Also, this study hypothesizes that the relationship between policy literacy and policy attitude can be moderated by cognitive subject and analyzed according to the type of cognitive subject involved. The multiple regression analysis based on the results of a survey that targeted 2,039 civil servants and ordinary citizens was utilized to verify the relationship. According to our research results, a high level of policy literacy about government 3.0 has a positive effect on policy support, and it is statistically significant. The effect of moderating variables, however, reveals that the impact of policy literacy on policy support varies depending on who the cognitive subject is. In addition, when the policy target groups are divided into civil servants and citizens, unlike the case of civil servants, a higher level of policy literacy on Government 3.0 in citizens does not necessarily lead to a higher level of policy support. The implication of this study is that unlike general misconception government officers do not groundlessly oppose government innovation programs. If there is enough information about the innovation, they will strongly support those changes. Also, in the case of citizens, rather than fancy slogans, it is necessary to guarantee transparent information and citizen participation. That can help ensure a positive correlation between policy literacy and policy support.
\end{abstract}

Keywords: Policy support, Policy literacy, Government innovation, Government 3.0

\section{Introduction}

"Government 3.0" is an administrative reform plan as well as a government innovation policy initiative of the Park Geun-hye administration. The objective of this innovation is to provide individualized public services through intra- and intergovernmental cooperation and publicprivate partnerships built on information communication technology (ICT). It also emphasizes sweeping changes to the administrative paradigm, shifting the workings of government from a government-centered to a citizen-centered approach (Lee 2014).

As a response to the 'smart' era, Government 3.0 is fully attainable from a technological standpoint, in view of Korea's ICT infrastructure and utilization levels. Ultimately, the success of this policy initiative depends on the response of the civil servants and citizens who will be affected by it and who will use the resulting systems. In other words, the effective 
attainment of the policy objectives of Government 3.0 depends on policy support and acceptance by civil servants and citizens. However, while much discussion has taken place concerning the tasks, challenges, and technical feasibility of Government 3.0, very little research has been done to systematically examine the level of public support for this policy and the factors behind such support. Government 3.0 is a policy that has involved massive publicity, under the widespread perception that the greater the public's understanding of a government policy is, the greater the support. However, no studies have been done on whether this publicity has had a positive effect on citizens' policy literacy or whether it has increased policy support and acceptance. Although many scholars recognize that policy literacy is a factor in determining attitudes and support towards policy, in reality, no consistent correlation has been found between policy support and policy literacy (Arcury 1990).

As such, this study analyzed factors that determine support from civil servants and the general public for the Government 3.0 policy initiative, utilizing a survey conducted by the Ministry of Culture, Sports and Tourism that targeted 2,039 civil servants and ordinary citizens. This study's analysis focuses particularly on the impact of literacy of Government 3.0.

\section{Theoretical argument}

\section{Government 3.0 as open innovation}

There has been ongoing discussion of government innovation to improve efficiency and democracy in public services. In particular, with the arrival of the smart era and ICT advances bringing changes not only to modes of communication between government and citizens, but also to systems used to carry out administrative operations, there is a rising need for corresponding government innovations (Geum and Han 2013; Jeong and Ha 2014).

Smart technology, in particular, has produced changes in how administrative services are provided and in systems of public governance. Owing to qualitative advances, along with a quantitative explosion of data over the past decade, data is being gathered in an increasing number of areas, and the picture it gives of the real world is becoming more and more precisely delineated ("The Data Deluge" 2010). The more widespread and far-reaching data becomes, the more effectively government will be able to apply innovations to analyze and predict the real world. Second, through the creation of 'derivative data', advances in data processing technology allow government to more easily obtain the data required for public policy decision-making and implementation. In addition, 'big data' processing capabilities are not restricted only to certain institutions. With the arrival of the open source data analysis tool Hadoop in 2006, it became possible for anybody to analyze an array of data at low cost (Hwang 2013). Through such changes, the channels of communication between government and the public have diversified, expanding from conventional face-to-face and telephone communication to milieus like SNSs and mobile smart apps. Public demand for disclosure of public data has also skyrocketed. In addition, with wider availability of big data analysis, there is growing demand for provision of personalized administrative services based on individualized information. Third, the use of smart mobile devices has also become common place in personal and workplace communications and in civil servants' work processes. The government should consider systems able to support civil servants' changing work practices to enhance task efficiency. Not only that, as the number of policy programs requiring cooperation between 
multiple agencies rises, there is a growing need to establish systems that allow information to be easily shared among public institutions. The smart technology advances alluded to above make such system conversions possible.

The 'Government 3.0' initiative of the Park Geun-hye administration was proposed as a new paradigm for the way government works, responsive to this smart era (Nam 2013; Song 2014). This government innovation program, which holds the core values of openness, sharing, communication, and collaboration, has the following major tasks (Ministry of Security and Public Administration 2013): first, to establish transparent and communicative government, fulfilling the public's right to access public information through proactive disclosure, promoting utilization of public data in the private sector, and strengthening public-private partnerships. Next, it also seeks to establish competent government, removing departmental 'silos' that represent barriers between government departments and agencies, supporting collaboration and communications by enhancing systems of government operations and leveraging big data to achieve scientific public administration. To establish citizen-centered, service-oriented government, it calls for providing customer-oriented integrated services. One-stop support for entrepreneurship and entrepreneurial activities is to be enhanced, and personalized services will be provided by deploying new ICT. Whereas Government 1.0 was government-centered and Government 2.0 was citizen-centered, Government 3.0 is regarded as a new government operation paradigm focused on attaining the happiness of individual citizens (Gu 2013).

Government 3.0 involves extending the principles of open innovation to the public sector. Open innovation can be viewed in terms of the phenomenon of online mass collaboration known as "crowdsourcing." With Government 3.0, the nearly ubiquitous use of Internet technology is being applied to the public sector, reaching the sphere of public administration (Hilgers and Ihl 2010). Governments communicate with their citizens via websites, and allow them to create and actively design public products and services in virtual spaces (Hilgers and Piller 2011). Such open innovation in the public sector contains three dimensions: Citizen Ideation and Innovation (the provision of ideas, knowledge, and innovations by the citizen as external consumer); Collaborative Innovation; and Collaborative Democracy (Hilgers and Ihl 2010). In the first dimension, Government 3.0 provides open innovation platforms in which citizens also take part. It promotes innovation by enabling citizens to put forth a variety of ideas for improving the quality of public services. In the second dimension of collaborative innovation, consumer-citizens are invited to exercise their creativity in shaping entirely new public products and services through idea competitions. As in the private sector, so-called innovation platforms bridging a public agency with external co-innovators can foster technological progress (Hilgers and Piller 2011). Next, when citizens participate in the traditional policy process and delivery of public services, this reinforces collaborative public administration and renders the administrative process more transparent and effective. Finally, in the third dimension, when public values are incorporated into decision-making and the quality of decisions is improved through the participation of citizens, as external actors beyond the internal bureaucrats who normally create policy, collaborative democracy is achieved (Hilgers and Ihl 2010). When open innovation is achieved by allowing internal and external agents to jointly participate and collaborate in the public decision-making process, it can enhance the delivery of individualized (customized) public services and the level of satisfaction. The administrative paradigm that makes this possible is Government 3.0. 
The relationship between policy literacy and policy support

If the propulsion of the administrative reform initiative known as Government 3.0 is seen as a policy process, it is very important to look into the responses of citizens and civil servants who are directly affected by the policy (Jeong and Ha 2014). The key factor determining the success or failure of a policy program is the consensus and support of the target groups involved (Jeong et al. 2015). Particularly in the case of administrative reform, it would not be an overstatement to say that its ultimate success depends on how much policy support from civil servants can be mobilized and continuously maintained.

Policy support is one form of policy attitude. In relevant research, this term is similar to such concepts as policy preference and policy acceptance. It refers to positive attitudes or behaviors expressed through individual evaluation of a given policy (Ajzen 1991). 'Attitude' consists of an emotional element based on an affective judgment, a cognitive element formed from an appraisal based on knowledge and information, and a behavioral element, that is, the intent behind certain actions (Zajonc 1984). In other words, attitude is determined by one's perceptions of a given target, which consequently influences one's behavior towards that target. Thus, policy support, which is a form of attitude towards policy, can be considered to consist of these same elements.

Up to now, studies on determinants for policy support have chiefly focused on elements like demographic characteristics, ideological factors, and self-interest. Since it is difficult to properly explain factors behind policy support solely through the variables of personal attributes, a limitation pointed out by Beck et al. (1987), a handful of more recent studies have assessed the impact of policy understanding or policy literacy (Steel and Lovrich 1998).

Policy literacy, the ability to identify and understand a policy based on policy information and knowledge, is generally measured by policy knowledge (Jung 2008). In the existing research setting policy literacy as an explanatory variable for government support, there is a widespread perception that the public's judgments and evaluations of government policies are formed through cognitive processes of individual citizens. The greater the policy literacy of the public is, the greater will be public support or acceptance for a given policy. On the other hand, when there is inadequate information on a policy or when there are low levels of understanding, the opposite outcome is seen. Most of the empirical studies have also backed up this assertion. Through experimentation, Eriksen and Fallan (1996) demonstrated that when disparities in knowledge of taxation exist, there are disparities in support for tax policy. An analysis by Steel and Lovrich (1998) focusing on support for social policy also showed that more active support for social policy is given by those possessing sufficient knowledge and information on public services like public education, roads, and parks. Other studies (Boeri et al. 2002; Boeri and Tabellini 2007) found that people with good knowledge of the costs and functions of pension systems showed stronger support for pension reform. And in a study on individual determinants of labor market policy preferences, those with sufficient information on related policy were less resistant to market-oriented labor market reform (Heinemann et al. 2009).

However, not every study has found a positive correlation between policy literacy and support. In a study on attitudes towards progressive taxation, participants showed a lower preference for progressive taxation (as opposed to a flat tax) when questions or situations were presented in concrete rather than abstract terms (Roberts et al. 1994). In another study examining public opinion on the Bush tax cuts in the early 2000s, Bartels (2005) argued that the reason why Americans showed strong support for such 
policies was because the majority of individuals were ill-informed, and did not understand about how their own tax burdens would be affected by the proposed tax cuts, which largely benefited only the wealthiest Americans. And in another study on redistribution through taxation, it was found that the greater the understanding of the tax system, the lower the support for redistribution policy, regardless of income level (Reed-Arthurs and Sheffrin 2010).

Although empirical studies have reported conflicting results, there has been very little discussion about the relationship between policy literacy and policy attitude. Generally, it has been considered that the greater policy literacy is, the more positive policy attitude becomes. That is a part of the reason why the government has recently spent a substantial amount on widely promoting the policy goal and content to the public. As mentioned earlier, however, the assumption of the correlation of policy literacy and policy attitude is based on insufficient empirical evidence. In addition, prior research has focused on analyzing public attitude toward social welfare policy or tax policy. There are very few studies on how policy literacy is related to attitude in administrative reforms and government innovation policies like Government 3.0.

This study analyzes the relationship between policy literacy and attitude in administrative reform initiative known as Government 3.0. To do this, this research formulates and examines a hypothesis that the more someone knows about Government 3.0, the more he/she would support it. Moreover, this study hypothesizes that the relationship between policy literacy and attitude depends on the cognitive subject and analyzes it. In other words, this study leads to a rich discussion about the relationship between policy literacy and attitude by examining whether who the cognitive subject is (for example, a civil servant or a citizen) will affect support degree.

\section{Research design}

In order to understand the basis for policy support on Government 3.0, we consider a range of factors found by scholars to affect policy attitude of the public. Figure 1 shows analytical model of our analysis. First, dependent variable is policy support for government 3.0 initiative. This variable consists in one's 'sympathy' on the importance of Government 3.0 and one's recognition of its 'effectiveness' for national happiness which is its goal. Independent variable is policy literacy in Government 3.0, and moderating variable is the cognitive subject, which is to verify that the cognitive subject will affect the relationship between policy literacy and policy support. In other words, we try to test whether two variables (dependent variable and independent variable) would vary with the cognitive subject (a civil servant or a citizen) who recognizes the policy and determines his/her attitude. Control variable is composed of policy concern, sex, age, and region which are proposed in preceding studies. In order to verify the relationship

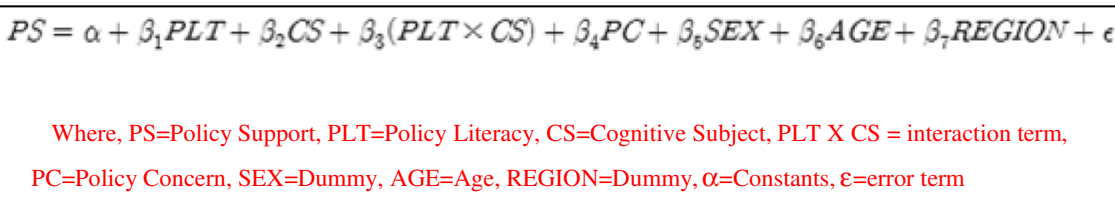

Fig. 1 Analytical model 
between independent variable and dependent variable and the influence of moderating variable on their relationship, this study uses multiple regression analysis.

\section{Data and measures}

This study uses data from the "Research Findings from a Public Opinion Survey on Sensory Reaction to Government 3.0" conducted by The World Research upon request from the Ministry of Culture, Sports and Tourism. This research is done by a telephone survey of 1,000 adults over the underage 19, with proportional sampling, sampled according to sex, age, regional population ratio and 400 current civil servants in government ministries, public corporations, and the relevant government departments during a 15-day period, from Sept. 15 to Sept. 29, 2014 (The World Research 2014).

First, dependent variable, policy support, is a type of public attitude, and it refers to positive attitudes or behaviors expressed through individual evaluation of a given policy (Ajzen 1991). Public attitude consists of an emotional element, a cognitive element, and a behavioral element (Zajonc 1984); but, generally, it is measured by an emotional and a cognitive element (Lazarus 1984). This study follows the general way, and analyzes one's sympathy on Government 3.0 (an emotional element) and one's recognition of its effectiveness (a cognitive element) in the degree of one's support of Government 3.0. Dependent variable is the sum of these scores. First, with regard to sympathy, the question we use from the "Research" is "how much do you sympathize with Government 3.0?"; respondents can choose from (1) Not at all to (4) Very much. To measure a cognitive element (effectiveness), the same set of answers is given to respondents in response to the question, "How much do you think Government 3.0 programs would be effective in order to achieve the goal of national happiness?."

Second, independent variable, policy literacy, signifies the ability to identify and understand a policy. The "Research" by The World Research this study uses gives respondents seven questions asking how much one knows about seven major service programs in Government 3.0. Those seven major programs are: (1) disclosure of information about the original documents signed by civil servants above directors (2) total history information on car service provided by the Ministry of Land, Infrastructure and Transport (3) disclosure of original price of 10 imported goods including mineral water, lipstick, etc. in Korea Customs Service (4) information offering service about fine dust and yellow-dust provided by the Ministry of Environment (5) issuing a driver license without physical examination through sharing information on health medical examination (6) disclosure of information on the comparison of price of non-payment item such as MRI in general hospital (7) offering information on appraisal authentication of all daycare centers. The survey asks whether one knows about these; the given answers are (1) Yes, I know them or I have heard about them ( 1 point) and (2) No, not at all ( 0 points). The score of policy literacy is the sum of these answers to questions about each service. Finally, moderating variable, the cognitive subject, is a dummy variable and concerns whether a respondent is a civil servant or an ordinary citizen. With civil servants set as the reference group, the coding used in this study applied 0 for civil servants and 1 for citizens.

Finally, control variables were measured as follows. First, the degree of policy concern refers to how much one generally concerns oneself with government policies. To 
measure it, we use the question, "How concerned are you with current government policy?" and give one point to (1) Not at all and 4 points to (4) Very much. The variable of sex involves the respondent's sex, with the dummy variable set to female; age is measured by the respondent's current legal age. The variable of region refers to the respondent's current residence, and is measured as a dummy variable according to the regions of the Capital area (Seoul, Incheon, Gyeonggi), the Chungbu area (Daejeon, Chungnam, Chungbuk, Gangwon), the Youngnam area (Busan, Daegu, Ulsan, Gyeongbuk, Gyeongnam), and the Honam area (Gwangju, Jeonbuk, Jeonnam, Jeju).

\section{Findings and discussions}

\section{Descriptive statistics}

In case of cognitive subject, $28.57 \%$ of respondents are civil servants and $71.43 \%$ are ordinary citizens (Table 1$)$. Over half of the respondents were male $(53.07 \%)$. With respect to regions, $45.29 \%$ of the respondents lived in the capital area, followed by the Youngnam area (25.50\%), Chungbu area (16.29\%), and Honam area (12.93\%).

Table 2 shows the number of observations, the mean values, standard deviation of the mean, and the min and max values of string variables used in the analysis. With respect to age, the mean value was 45.13 , with the oldest respondent being 92 years old. The mean value of policy concern was 2.879 and policy literacy was 2.709 . In the case of policy literacy, the mean value was 2.709 out of 7.0.

Table 3 shows differences according to the key variable, namely status as either an ordinary citizen or civil servant. In all three categories including policy support, policy literacy, and policy concern, the mean values for citizens were higher than for civil servants. Meanwhile, the mean age of civil servants was higher than the citizens.

\section{Determinants of policy support for Government 3.0}

Table 4 shows the result of multiple regression analysis examining how the degree to which policy support for Government 3.0 initiative is influenced by cognitive subject status and policy literacy.

Significantly, model 1, which includes an independent variable, has more power of explanation $(27.62 \%)$ than the reference model including only a control variable (25.5\%). Moreover, generally, a high level of policy literacy in Government 3.0 has a positive effect on support for it.

Next, support for this innovation policy was found to be higher in respondents who were aware of a newly-introduced government service that actualizes Government 3.0, how it was done, and what the resulting changes would be. That is, when respondents knew about some specific change in government service produced by the adoption of Government 3.0, there

Table 1 Descriptive statistics of categorical variables

\begin{tabular}{llllllll}
\hline Variable & & Frequency & Percent (\%) & Variable & Frequency & Percent (\%) \\
\hline Cognitive Subject & Civil Servant & 400 & 28.57 & Region & Capital area & 634 & 45.29 \\
Cognitive Subject & Citizen & 1,000 & 71.43 & Region & Chungbu & 228 & 16.29 \\
Cognitive Subject & Total & 1,400 & 100.00 & Region & Youngnam & 357 & 25.50 \\
Sex & Female & 657 & 46.93 & Region & Honam & 181 & 12.93 \\
Sex & Male & 743 & 53.07 & Region & Total & 1,400 & 100.00 \\
Sex & Total & 1,400 & 100.00 & & & & \\
\hline
\end{tabular}


Table 2 Descriptive statistics of string variables

\begin{tabular}{llcccc}
\hline Variable & Obs. & Mean & Std. Dev. & Min & Max \\
\hline Policy Support & 1,292 & 2.784 & 0.723 & 1 & 4 \\
Policy Literacy & 1,400 & 2.709 & 1.911 & 0 & 7 \\
Policy Concern & 1,394 & 2.879 & 0.814 & 1 & 4 \\
Age & 1,400 & 45.138 & 15.486 & 19 & 92 \\
\hline
\end{tabular}

was more sympathy for the policy, and its effectiveness was considered higher, compared with respondents who did not know about such service changes.

However, the efficacy of moderating variable in this result should be noticed more. Model 2 , which adds interaction terms of independent variable and moderating variable, has an increasing power of explanation $(\mathrm{F}=54.75, \mathrm{p}<.000)$, and the influence of interaction terms is proven to be meaningful statistically $(\beta=-.038, \mathrm{p}<.000)$. In other words, the influence of policy literacy over support for the policy varies depending on whether the cognitive subject is a civil servant or a citizen. We could see that when the cognitive subject is a citizen, a positive effect of policy literacy on policy support is significantly decreased. Figure 2 shows that you get the same value for the slope of a line from its graph, which indicates the relationship between policy literacy and policy support, irrespective of the cognitive subject. It, however, also suggests that in case of the citizen, policy literacy has only slight impact on policy support.

Table 5 illustrates the result of regression analysis by subject group. In civil servant groups, policy literacy has shown a significant impact on policy support. On the other hand, in the citizen policy literacy was not significant. Policy concern has a significant effect on policy support in both groups.

\section{Discussion}

Previous relevant research (Jeong and Ha, 2014) argues that it is problematic for the mass media and academia to see resistance of the bureaucracy as the reason why Government 3.0 did not go well. According to the existing perspective, a government innovation program requires and almost forces civil servants to change the way they work, which generally leads to resistance of civil servants. Based on this perspective, most experts consider the lowreceptivity of the civil servant as an obstacle to Government 3.0. The above empirical study, however, reveals that not all civil servants simply feel negative about this government innovation policy, Government 3.0, through in-depth interviews of civil servants working in a local government. Furthermore, it points out that other factors, rather,-such as, diverse and contradictory interpretations over Government 3.0 because of its ambiguity and the

Table 3 Comparison of two groups

\begin{tabular}{lllcccc}
\hline Variable & Group & Obs. & Mean & Std. Dev. & Min & Max \\
\hline Policy Support & Citizen & 400 & 3.140 & 0.573 & 1 & 4 \\
Policy Support & Civil Servant & 892 & 2.624 & 0.726 & 1 & 4 \\
Policy Literacy & Citizen & 400 & 3.853 & 1.939 & 0 & 7 \\
Policy Literacy & Civil Servant & 1,000 & 2.252 & 1.697 & 0 & 7 \\
Policy Concern & Citizen & 400 & 3.178 & 0.691 & 1 & 4 \\
Policy Concern & Civil Servant & 994 & 2.760 & 0.830 & 1 & 4 \\
Age & Citizen & 400 & 38.998 & 7.332 & 19 & 58 \\
Age & Civil Servant & 1,000 & 47.594 & 17.124 & 19 & 92 \\
\hline
\end{tabular}


Table 4 Results of multiple regression analysis

\begin{tabular}{|c|c|c|c|}
\hline & & $\begin{array}{l}\text { Model } 1 \\
\text { (standard error) }\end{array}$ & $\begin{array}{l}\text { Model } 2 \\
\text { (standard error) }\end{array}$ \\
\hline \multicolumn{2}{|l|}{ Policy Literacy } & $0.030^{* * *}(0.010)$ & $0.055^{* * *}(0.016)$ \\
\hline \multicolumn{2}{|c|}{ Cognitive Subject (Reference = Civil Servant) } & $-0.417^{* * *}(0.043)$ & $-0.294^{* * *}(0.079)$ \\
\hline \multicolumn{2}{|l|}{ Policy Literacy X Cognitive Subject } & & $-0.038^{*}(0.020)$ \\
\hline \multicolumn{2}{|l|}{ Policy Concern } & $0.270^{* * *}(0.024)$ & $0.267^{* * *}(0.024)$ \\
\hline \multicolumn{2}{|l|}{ Sex (Reference = Female) } & $0.080^{* *}(0.035)$ & $0.079^{* *}(0.035)$ \\
\hline \multicolumn{2}{|l|}{ Age } & $0.008^{* * *}(0.001)$ & $0.008^{* * *}(0.001)$ \\
\hline Area (Reference $=$ A capital area) & Chungbu & $0.027(0.050)$ & $0.029(0.050)$ \\
\hline Area (Reference = A capital area) & Youngnam & $0.064(0.043)$ & $0.060(0.043)$ \\
\hline Area (Reference $=$ A capital area) & Honam & $-0.135^{* *}(0.055)$ & $-0.136^{* *}(0.055)$ \\
\hline \multicolumn{2}{|l|}{ Constants } & $1.816^{* * *}(0.088)$ & $1.734^{* * *}(0.098)$ \\
\hline \multicolumn{2}{|l|}{ No. of Observations } & 1,289 & 1,289 \\
\hline \multicolumn{2}{|l|}{$R^{2}$ (Adjusted $R^{2}$ ) } & $0.2762(0.2716)$ & $0.2781(0.2730)$ \\
\hline \multicolumn{2}{|l|}{ F-value } & $61.04^{* * *}$ & $54.75^{* * *}$ \\
\hline
\end{tabular}

Note: ${ }^{*} p<0.1, * * 0<0.05,{ }^{* *} p<0.01$

communication gap inside governments-reduce the policy receptivity and the degree of policy support of the civil servant. This study also shows that as the civil servant knows more about the goal and content of the policy, the degree of policy support, i.e. sympathy for this innovation initiative and recognition of its effectiveness, becomes higher. Whereas, another policy target group, the citizen, shows somewhat different result. In case of the citizen, although he/she knows well about the goal of this policy and the content of its subprograms, it does not lead to policy support. This is aptly illustrated by the results of a comparative analysis of the two groups (Table 5).

Judging from the point of view of open innovation, if the consumer of public services is involved in the production and delivery of public services (Patra and Krishna 2015), he/she

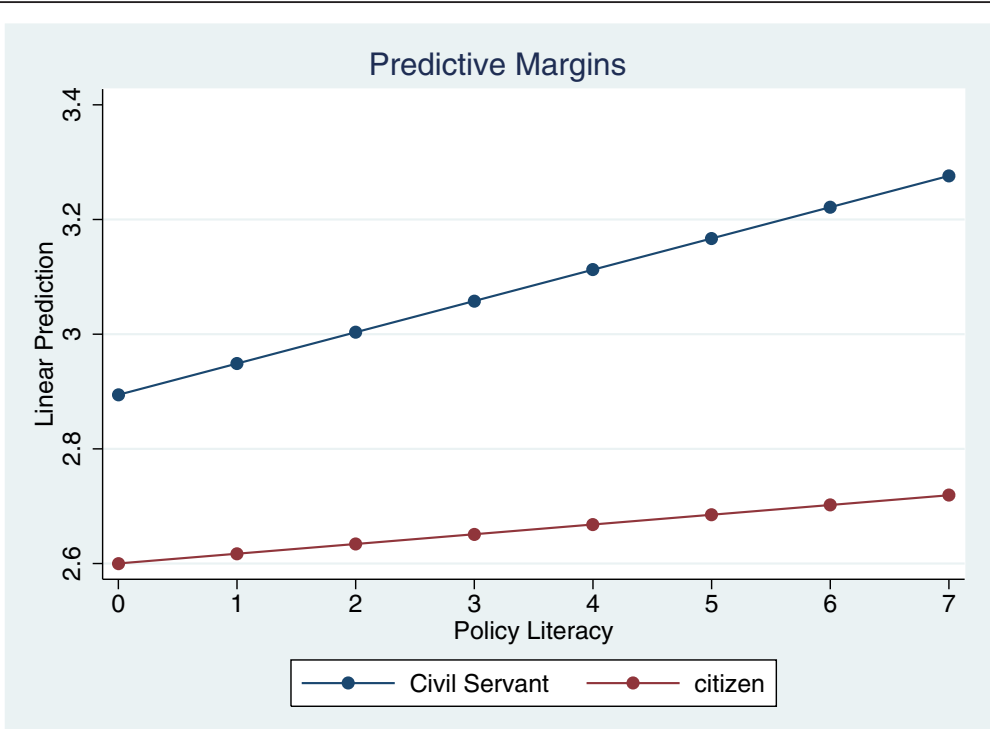

Fig. 2 The moderating effect of cognitive subject 
Table 5 Comparison of subject groups

\begin{tabular}{|c|c|c|c|}
\hline \multicolumn{2}{|l|}{ Variable } & \multirow{2}{*}{$\begin{array}{l}\text { Civil servant } \\
\text { (Standard error) }\end{array}$} & \multirow{2}{*}{$\begin{array}{l}\text { Citizen } \\
\text { (Standard error) }\end{array}$} \\
\hline Variable & & & \\
\hline Policy Literacy & & $0.038^{* * *}(0.013)$ & $0.020(0.013)$ \\
\hline Policy Concern & & $0.381^{* * *}(0.039)$ & $0.234^{* * *}(0.030)$ \\
\hline Sex (Reference $=$ Female) & & $0.074(0.050)$ & $0.081 *(0.046)$ \\
\hline Age & & $0.009^{* *}(0.003)$ & $0.008^{* * *}(0.001)$ \\
\hline Region (Reference $=$ A capital area) & Chungbu & $-0.074(0.063)$ & $0.090(0.069)$ \\
\hline Region (Reference = A capital area) & Youngnam & $-0.015(0.064)$ & $0.075(0.054)$ \\
\hline Region (Reference = A capital area) & Honam & $-0.143^{* *}(0.071)$ & $-0.165^{* *}(0.075)$ \\
\hline Constant & & $1.444^{* * *}(0.156)$ & $1.507^{* * *}(0.096)$ \\
\hline N & & 400 & 889 \\
\hline$R^{2}$ (Adjusted $R^{2}$ ) & & $0.3348(0.3229)$ & $0.1572(0.1505)$ \\
\hline $\mathrm{F}$ & & $28.18^{* * * *}$ & $23.48 * * *$ \\
\hline
\end{tabular}

Note: ${ }^{*} p<0.1,{ }^{* *} p<0.05,{ }^{* * *} p<0.01$

experiences a higher level of satisfaction with public services (Della Corte et al. 2015), which consequently enhances his/her attitude toward public services. In the case of Government 3.0, a civil servant involved in policy formation as an internal consumer should show higher support for Government 3.0 than citizens as external consumers.

While civil servants are a group targeted by the Government 3.0 innovation policy, they are at the same time the propelling force of that policy. This means that their attitude towards the policies they are charged with carrying out is more accepting than that of ordinary citizens. Government 3.0 is an innovation policy which, through proactive disclosure of information held by the government, aims to provide individualized services through participation and communication. Public officials believe that transparency and responsiveness can be improved and public happiness can be attained simply by disclosing information that they previously held as proprietary. In other words, their view is that, as civil servants, they have served the public well, and if the 'hardware' of Government 3.0 is adopted, these services can be provided a bit more easily.

However, the appraisal of the public at large is that the Government 3.0 initiative being trumpeted by the government is a mere slogan, and that the government's monopoly on information will continue unabated. They feel that, because the government is likely to release only information for which disclosure would not be problematic, rather than the information the public wants, there will not be any particular results to speak of. In other words, the general public thinks that Government 3.0 cannot be accomplished just by adopting high-tech advances like semantic technology and cloud computing, but rather requires changes in the attitudes and behavior of civil servants. Such disparities in the perceptions of knowing subjects lead to disparities in policy support, that is, in how much sympathy is given to the policy and how effective it is perceived to be.

On the other hand, this is how much impact control variable has on policy support: first, if a respondent concerns more over general government policies, he/she tends to support Government 3.0 more. Demographically, the female and the aged are more likely to support Government 3.0 than the male and the young. Lastly, it was also found that policy 
support for Government 3.0 varied by region. Lastly, it was also found that policy support for Government 3.0 varied by region. Residents of the Youngnam and Chungbu areas do not particularly support Government 3.0 more than those of the capital area. However, in the Honam area, which is marked by opposition to the present administration, policy support for Government 3.0 appeared lower than in other regions. It can be assumed that one's attitude towards the political power in charge of national affairs, including government innovation, is connected with policy support. In that vein, regional fissures in the Korean political environment are reflected in support for government innovation policy.

\section{Conclusion}

This study analyzed factors affecting policy support for the government innovation policy known as Government 3.0, centering on knowing subjects and level of policy literacy. Knowing subjects were divided into civil servants and ordinary citizens. Policy support for Government 3.0, in terms of sympathy for the policy and perceptions of its effectiveness, was analyzed using a multiple regression model that included moderating variables.

The analysis result shows that generally, a high level of policy literacy on Government 3.0 has a positive effect on policy support, and it is statistically meaningful. It presents the grounds for an argument about the relationship between these two variables, centering on the citizen's perspective over social policies or environmental policies (Steel and Lovrich 1998; Boeri and Tabellini 2007). The effect of Moderating Variable, however, reveals that the impact of policy literacy over policy support varies depending on who the cognitive subject is. In addition, when policy target group is divided into the civil servant and the citizen, it is proven that, unlike the civil servant, in case of the citizen, a higher level of policy literacy on Government 3.0 does not necessarily lead to a higher level of policy support. A statistically significant positive effect was also found to correlate with age, demonstrating that older Koreans hold more positive attitudes towards Government 3.0. It was also found that region of residence affects policy support for Government 3.0, indicating that the regional fissures seen in preferences towards the political power are also reflected in attitudes towards government innovation policy.

In light of significant differences in the perceptions of civil servants, as the exclusive providers of information through Government 3.0, and ordinary citizens, as the consumers of information, one implication of this study is that, rather than simply adopting high-tech innovations or revamping hardware, the government needs soft strategies to change the perceptions and behavior of civil servants. The next implication is that active publicity is needed, since the more aware people are of services newly introduced through Government 3.0, the greater their policy support becomes. Rather than grandiose slogans, if disclosure and participation are ensured, centering on service areas that actually matter to the general public, and if that is publicized, then public sympathy for the Government 3.0 policy initiative can be readily formed.

The following limitations of this study should, however, be noted. As it draws on secondary sources, it did not consider certain variables that are known to influence policy support, such as interests, ideologies, and governmental trust. In future studies, more rigorous research design and analysis models are needed to analyze determinants of policy support for Government 3.0. 


\section{Appendix 1}

Table 6 Correlations

\begin{tabular}{lclll}
\hline & Policy support & Policy literacy & Policy concern & Age \\
\hline Policy support & 1.000 & & & \\
Policy literacy & $0.257^{* * *}$ & 1.000 & & \\
Policy concern & $0.431^{* * *}$ & $0.292^{* * *}$ & 1.000 & 1.000 \\
Age & $0.147^{* * *}$ & $-0.120^{* * *}$ & $0.173^{* * *}$ & \\
\hline
\end{tabular}

Note: ${ }^{*} p<0.1,{ }^{* *} p<0.05,{ }^{* * *} p<0.01$

\section{Appendix 2}

Table 7 Survey items

\begin{tabular}{|c|c|c|c|}
\hline Cate & Variable & Survey items & Measurement \\
\hline Dependent & Policy Support Sympathy & $\begin{array}{l}\text { How much do you sympathize } \\
\text { with Government } 3.0 \text { Policy? }\end{array}$ & $\begin{array}{l}\text { (1) Not at all to (4) Very much } \\
\text { four-point scale }\end{array}$ \\
\hline Dependent & Policy Support Effectiveness & $\begin{array}{l}\text { How effective do you think } \\
\text { Government } 3.0 \text { programs } \\
\text { would be in achieving the } \\
\text { goal of national happiness? }\end{array}$ & $\begin{array}{l}\text { (1) Not at all } \sim \text { (4) Very much } \\
\text { four-point scale }\end{array}$ \\
\hline Independent & Cognitive Subject & Status of Respondents & (1) Citizen, (2) Civil Servant \\
\hline Independent & Policy Literacy & $\begin{array}{l}7 \text { questions asking how much } \\
\text { the respondent knows about } \\
7 \text { major service programs in } \\
\text { Government 3.0. Those } \\
7 \text { major programs are: } \\
\text { (2) disclosure of information } \\
\text { about the original documents } \\
\text { signed by civil servants above } \\
\text { directors (2) total history } \\
\text { information on car service } \\
\text { provided by the Ministry of } \\
\text { Land, Infrastructure and } \\
\text { Transport (3) disclosure of } \\
\text { original price of } 10 \text { imported } \\
\text { goods including mineral water, } \\
\text { lipstick, etc. in Korea Customs } \\
\text { Service (4) information offering } \\
\text { service about fine dust and } \\
\text { yellow-dust provided by the } \\
\text { Ministry of Environment } \\
\text { (5) issuing a driver license } \\
\text { without physical examination } \\
\text { through sharing information } \\
\text { on health medical examination } \\
\text { (6) disclosure of information } \\
\text { on the comparison of price } \\
\text { of non-payment item such } \\
\text { as MRI in general hospital } \\
\text { (7) offering information on } \\
\text { appraisal authentication of all } \\
\text { daycare centers. }\end{array}$ & $\begin{array}{l}\text { (1) Yes, I know them or I have } \\
\text { heard about them ( } 1 \text { point) } \\
\text { (2) No, not at all ( } 0 \text { point) [The } \\
\text { score of policy literacy is the } \\
\text { sum of these answers to } \\
\text { questions about each service] }\end{array}$ \\
\hline Control & Policy Concern & $\begin{array}{l}\text { How concerned are you with } \\
\text { current government policy? }\end{array}$ & $\begin{array}{l}\text { (1) Not at all to (4) Very much } \\
\text { four-point scale }\end{array}$ \\
\hline Control & Sex & - & (1) Male, (2) Female \\
\hline Control & Age & - & - \\
\hline
\end{tabular}


Table 7 Survey items (Continued)

\begin{tabular}{|c|c|c|c|}
\hline Control & Region & Residence of Respondent & $\begin{array}{l}\text { Capital area (Seoul, Inchoen, } \\
\text { Gyeonggi), Chung-bu (Daejeon, } \\
\text { Chungnam, Chungbuk, } \\
\text { Gangwon), Youngnam(Busan, } \\
\text { Daegu, Ulsan, Gyeongbuk, } \\
\text { Gyeongnam), Honam (Gwangju, } \\
\text { Jeonbuk, Jeonnam, Jeju) }\end{array}$ \\
\hline
\end{tabular}

\section{Author details}

${ }^{1}$ BK21 Plus Program, GSPA, Seoul National University, 1 Gwanak-ro, Gwanak-gu, Seoul, Republic of Korea. ${ }^{2}$ College of Liberal Arts, Wonkwang University, 460 Iksan-daero, Iksan, Jeollabuk-do, Korea, Republic of.

Received: 2 December 2015 Accepted: 16 December 2015

Published online: 29 December 2015

\section{References}

"The Data Deluge" (2010 Feb. 25 ${ }^{\text {th }}$ ). The Economist.

Ajzen I. The theory of planned behavior. Organ Behav Hum Decis Process. 1991;50(2):179-211.

Arcury TA. Environmental attitudes and environmental knowledge. Hum Organ. 1990;49(4):300-4.

Bartels L. Homer gets a tax cut: Inequality and public policy in the American mind. Perspect Politics. 2005;3(1): 15-31.

Beck PA, Rainey HG, Nicholls K, Tram C. Citizen views of taxes and services: A tale of three cities. Soc Sci Q. 1987:68(2):223-43.

Boeri T, Tabellini G. Does information increase political support for pension reform? Bocconi University and IGIER, mimeo. 2007.

Boeri T, Börsch-Supan AH, Tabellini G. Pension reforms and the opinions of European citizens. Am Econ Rev. 2002:92:396-401.

Della Corte V, lavazzi A, D'Andrea C. Customer involvement through social media: The cases of some telecommunication firms. J Open Innov. 2015;1:10. doi:10.1186/s40852-015-0011-y.

Eriksen K, Fallan L. Tax knowledge and attitudes towards taxation: A report on a quasi-experiment. J Econ Psychol. 1996;17:387-402.

Geum $\mathrm{CH}$, Han BY. Searching for the implementation system of local Government 3.0. Korea Local Admin Rev. 2013;27(3):41-64.

Gu MS. The trend of policy, Government 3.0. Disaster Saf Contr. 2013:15(3):38-42

Heinemann F, Bischoff I, Hennighausen T. Choosing from the reform menu card: Individual determinants of labour market policy preferences. Jahrbücher für Nationalökonomie und Statistik. 2009;229:180-97.

Hilgers D, Ihl C. Citizensourcing: applying the concept of open innovation to the public sector. Int J Public Particip. 2010;4(1):67-88

Hilgers D, Piller FT. A Government 2.0: Fostering public sector rethinking by open innovation. 2011. http:// innovationmanagement.se/wp-content/uploads/2011/02/A-Government-2.0-Fostering-Public-Sector-Rethinkingby-Open-Innovation.pdf. Accessed 29 Nov 2015.

Hwang JS. Gov.3.0: Concept establishment of e-Government and promotion strategy formulation, The Korean Association Annual Meeting (Spring 2013). 2013.

Jeong JY, Ha MC. The implementation of administrative reform: A case study on the implementation acceptability of Government 3.0. Res Gov Study. 2014:20(3):279-353.

Jeong CG, Choi JW, Lee SW, Jung JG, Jung KH. The principles of public policy. Seoul: Dae-Myung Publishing Co.; 2015.

Jung $\mathrm{KH}$. An empirical analysis of the policy literacy function: A focus on civic activities. Korean J Public Admin. 2008;46(4):73-104.

Lazarus RS. On the primacy of cognition. Am Psychol. 1984;39(2):124-9.

Lee JW. A Study on the correspondence between government paradigm and information disclosure paradigm. J Korean Assoc Region Inform Soc. 2014;17(2):147-72.

Ministry of Security and Public Administration. Government 3.0, A source book of the Ministry of Security and Public Administration. 2013.

Nam TW. Government 3.0 in Korea: fad or fashion? Proceedings of the 7th International Conference on Theory and Practice of Electronic Governance. 2013.

Patra SK, Krishna W. Globalization of R\&D and open innovation: Linkages of foreign R\&D centers in India. J Open Innov. 2015;1:7. doi:10.1186/s40852-015-0008-6.

Reed-Arthurs R, Sheffrin SM. Understanding the public's attitudes towards redistribution through taxation. In: Tulane Economics Working Paper Series, Working Paper 1005. 2010. September 2010

Roberts ML, Hite PA, Bradley CF. Understanding attitudes toward progressive taxation. Public Opin Q. 1994:58(2):165-90.

Song I. Emerging Internet technology \& service toward Korean Government 3.0. KSII Transact Internet Inform Syst. 2014;8(2):540-6.

Steel BS, Lovrich NP. Determinants of public support for tax and expenditure initiatives: An Oregon and Washington case study. Soc Sci J. 1998;35(2):213-30.

The World Research. Research findings from a public opinion survey on sensory reaction to Government 3.0. The research report of the Ministry of Culture, Sports and Tourism. 2014.

Zajonc RB. The interaction of affect and cognition. In: Scherer KR, Ekman P, editors. Approaches to emotion. Hillsdale, NJ: Lawrence Erlbaum Associates; 1984. p. 239-46. 